\title{
Horizonte, v. 10, n. 26, abr./jun. 2012
}

\section{Dossiê: Juventude e Religião}

Dossier: Youth and Religion

\author{
Paulo Agostinho N. Baptista* \\ Rodrigo Coppe Caldeira**
}

Horizonte está em festa! Parabéns aos seus leitores, autores, avaliadores, editores, estagiários e todos os colaboradores pelos 15 anos de nossa revista. E, justamente, na data de seu aniversário ela recebeu um presente: a classificação A2 do Qualis de sua área acadêmica Filosofia/sub-área Teologia. Agradecemos a todos pela dedicação que produziu esse avanço e contamos que essa parceria se prolongue e expresse a qualidade das publicações da revista. E não vamos parar aí!

O editorial deste número tem o título do dossiê - Juventude e Religião - e é do Magnífico Reitor da PUC Minas - Dom Joaquim Giovani Mol Guimarães - o primeiro editor, aquele que começou essa jornada exitosa de Horizonte.

O Dossiê Juventude e Religião traz oito artigos. No primeiro - A juventude da Teologia da Libertação - Flávio Sofiati analisa as mudanças ocorridas na Pastoral da Juventude do Brasil (PJB), entre 1980 e 1990, na conjuntura de ascensão pentecostal. Partindo de uma contextualização histórica, o autor aponta para o método pedagógico e as opções políticas da Pastoral nessas décadas. Em 1980, observa-se a ênfase na dimensão política, com participação em inúmeros movimentos sociais, enquanto na década de 1990 a PJB teria se reformulado, enfatizando as dimensões pessoais e teológicas.

\footnotetext{
* Doutor e mestre em Ciências da Religião (UFJF), diretor acadêmico e professor adjunto da PUC Minas, editor-gerente de Horizonte. País de origem: Brasil. E-mail: pagostin@ gmail.com.

** Doutor em Ciência da Religião (UFJF, 2009), Prof. Adjunto da PUC Minas, Departamento de Ciências da Religião. Editor associado de Horizonte. País de origem: Brasil. E-mail: rcoppe@ hotmail.com
} 
O segundo artigo - Jeunes e religieux au Québec: Du catholicismo ethnique au catholicisme de marché - do pesquisador Jean-Philippe Perreault, da Université Laval, aborda o imaginário religioso dos jovens de Québec, levantando a hipótese da formação na província canadense de um "catholicisme de marché”, isto é, um catolicismo de mercado, caracterizado por uma conexão do catolicismo à cultura da sociedade de consumo.

O próximo artigo do dossiê, assinado por Eduardo Gusmão de Quadros - Sem lenço, sem documento e com uma Bíblia nas mãos: o movimento estudantil evangélico nos anos sessenta -, estuda dois movimentos: a Associação Cristã Acadêmica e a Aliança Bíblica Universitária do Brasil. A fim de compreender a atuação de ambos os movimentos, Gusmão de Quadros contextualiza o protestantismo brasileiro após a Segunda Grande Guerra e analisa as organizações estudantis evangélicas, marcadas por diferenças identitárias. Por fim, aborda o contexto repressivo a partir de 1964, com o fito de apresentar as diferentes propostas teológicas, práticas pastorais e os embates com a instituição, na medida em que os jovens evangélicos articulavam sua experiência religiosa com o engajamento político.

No quarto artigo são apresentados os resultados de pesquisa realizada em escolas estaduais de Belo Horizonte, a partir da análise dos seus Projetos Políticos Pedagógicos, verificando a presença da formação humanista. Os pesquisadores Roberlei Panasiewicz, Paulo Agostinho N. Baptista e os bolsistas Alex de Souza Braga e Maria Emília Abreu Carneiro, no artigo Educação e cidadania: a formação humanista da juventude nos Projetos Políticos Pedagógicos, mostram os limites dessa presença ao mesmo tempo que indicam a importância da escola desafiada por situações sociais, políticas e econômicas que suscitam o desejo de paz, tolerância e justiça.

José Pereira Coutinho, no artigo Beliefs, practices and attitudes of portuguese undergraduate youth (Crenças, práticas e atitudes da juventude universitária portuguesa), traz a lume os resultados de sua pesquisa de doutorado, a partir de um questionário aplicado a quinhentos estudantes de universidades públicas de Lisboa, destacando suas crenças em 
relação aos dogmas cristãos, a frequência à Missa e seus posicionamentos sobre casamento e sexualidade.

No sexto artigo do dossiê - Seguir e servir a Cristo pobre: juventude, idéias e renúncias na Toca de Assis -, Rodrigo Portella objetivou compreender a opção de adesão de jovens à Toca de Assis, movimento católico que se caracteriza pela adoção de estilo de vida marcado por pobreza radical, renúncia a bens e estudos formais, desenvolvendo trabalho com "moradores de rua".

Mary Esperandio e Alexsander Lopes apresentam uma cartografia dos processos de subjetivação (criação de modos de existência) da juventude católica de uma paróquia na região metropolitana de Curitiba, no artigo "Juventude e religiosidade: cartografia dos processos de subjetivação de jovens católicos em uma comunidade de fé”.

O último artigo do dossiê - Bola de Neve”: Um fenômeno pentecostal contemporâneo, Lídice Meyer Pinto Ribeiro e Danilo da Silva Cunha apresentam uma análise antropológica dessa igreja pentecostal situada no Tatuapé, Zona Leste da cidade de São Paulo, marcadamente jovem, visando compreender a estrutura do culto, o perfil dos membros e as estratégias de comunicação utilizadas.

A seção de Temática Livre apresenta quatro artigos, com temas variados. Áurea Marin Burocchi, em Deus Trindade, apresenta sua reflexão sobre a formulação dogmática da Trindade tendo como pano de fundo a contribuição teológica de Bruno Forte.

$\mathrm{O}$ artigo As lendas e a imaginação simbólica: uma metodologia para a sala de aula, de Eunice Simões Lins Gomes, Pierre Normando Gomes-da-Silva e Claudiana Soares da Costa, apresenta uma metodologia aplicada em salas de aula das primeiras séries do Ensino Fundamental com o objetivo de despertar a imaginação simbólica dos alunos, utilizando-se de lendas presentes nos livros didáticos de Ensino Religioso. 
Júlio Cezar Adam, no artigo Da ficção científica para a ficção religiosa: idéias para pensar o cinema de ficção científica como o culto da religião vivida, discute o papel da teologia e das ciências da religião a partir do discurso cinematográfico. Na sua visão, o cinema é compreendido como forma de culto e ritual, cumprindo a função que mitos e ritos sagrados desempenham na vida dos indivíduos ao longo dos tempos.

Por fim, Paulo Sérgio Lopes Gonçalves apresenta A religião à luz da fenomenologia hermenêutica heideggeriana. A partir dos conceitos "fenomenologia", "hermenêutica" e "facticidade", o autor reflete sobre como Heidegger desenvolve esses conceitos na análise das cartas aos Gálatas e aos Tessalonicenses e do livro X das Confissões de Agostinho. Conclui que a religião é experiência religiosa, desenvolvida em meio à vida cotidiana, com todas as suas tensões, inquietações e projeções.

Quatro Comunicações são apresentadas neste número: A abordagem do texto cristão em Erich Auerbach, de Victor de Oliveira Pinto Coelho; Diálogo entre a tradição bíblica e a construção do discurso teológico ambiental cristão, de Amelia Ferreira Martins Limeira e Maristela Oliveira de Andrade; Conflitos de gerações: Gustavo Corção e a juventude Católica, de Christiane Jalles de Paula; e Um outro mundo já começou: questões para a escatologia cristã, de Orivaldo Pimentel Lopes Júnior.

Os Resumos são de Dissertações defendidas no Programa de Pós-graduação em Ciências da Religião da PUC Minas: Congada e Reinado: história religiosa da irmandade negra em Jequitibá-MG, de Carlos Roberto Moreira do Santos; Espiritualidade no processo de adoecimento e terminalidade, de Maria Emídia de Melo Coelho; A manifestação da Umbanda na Região Metropolitana de Belo Horizonte: da tradição à contemporaneidade, de Anderson Marinho Maia; A aceitação irônica do sagrado: Gianni Vattimo e a secularização, de Marcos Paulo Nogueira da Silva; e Filhos de Maria: uma devoção masculina em torno à reza do terço, de Elizabeth Raymunda de Carvalho Gontijo. 
As Resenhas finalizam esse número e são de João Batista Libanio, que analisa a obra $A s$ comunidades podem pedir ordenação de ministros próprios? (Fritz Dom Lobinger); de Rodrigo Coppe Caldeira, tratando do livro Para entender o catolicismo hoje (Luiz Felipe Pondé); e de Daniel Foschetti Gontijo, abordando o livro Religião para ateus (Alain de Botton).

Aos leitores de Horizonte, ótima leitura e, novamente, Parabéns! 